\title{
ПРОБЛЕМНІ ПИТАННЯ ДІАГНОСТИКИ
} ТРОФОБЛАСТИЧНОЇ ХВОРОБИ

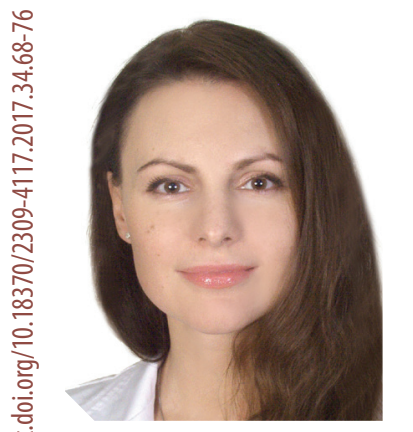

\section{Н.Ю. ПЕДАЧЕНКО}

д. мед. н., доцент, професор кафедри акушерства, гінекології та перинатології Національної медичної академії післядипломної освіти ім. П.Л. Шупика

ORCID: 0000-0002-0821-2943

\section{O.I. MУХOMOP}

к. мед. н., керівник Центру ультразвукової діагностики та інтервенційної сонографії клінічної лікарні «Феофанія», м. Київ ORCID: 0000-0002-7918-1945

\section{К.Л. АВЕТИСЬЯН}

к. мед. н., завідувач відділенням патоморфології Київського міського клінічного ендокринологічного центру

ORCID: 0000-0003-0352-2528

\section{Ю.С. ДЕНИСЕНКО}

лікар акушер-гінеколог, інтерн кафедри акушерства, гінекології та перинатології НМАПО ім П.Л. Шупика

ORCID: 0000-0003-1518-2663

\section{Контакти:}

Педаченко Наталія Юріївна НМАПО ім. П.Л. Шупика, кафедра акушерства, гінекології та перинатології 04074, Київ, Мостицька, 11 тел.: + 380 (44) 2054946 e-mail: clinicnv@gmail.com

\section{ВСТУП}

Дослідження останніх десятиліть свідчать про те, що наразі немає єдиної стратегії в своєчасному виявленні та лікуванні гестаційної трофобластичної хвороби, оскільки діагностика даного стану нечітка та потребує новітніх впроваджень та методик.

Трофобластична хвороба вагітності - збірне поняття [3], яке включає групу доброякісних і злоякісних новоутворень трофобласту. Захворювання належить до рідкісних пухлин (1-2,5\% серед злоякісних новоутворень жіночих статевих органів) і розвивається переважно в жінок дітородного віку. Найчастішою формою трофобластичних пухлин $\epsilon$ міхурцевий занесок (МЗ). Гестаційна трофобластична хвороба - патологія, що супроводжується проліферацією трофобластної тканини та призводить до підвищеного рівня хоріонічного гонадоторопіну людини (ХГЛ).

\section{АНАЛІЗ ЛІТЕРАТУРНИХ ДАНИХ ТА} \section{ПОСТАНОВКА ЗАВДАННЯ ДОСЛІДЖЕННЯ}

Спроба охарактеризувати захворюваність на М3 викликає певні труднощі $[5,9,11,12]$. Проблема накопичення достовірних епідеміологічних даних може бути пов'язана з відсутністю узгодженості в описі клінічних випадків [11, $12,25]$, некоректною характеристикою категорій населення, що знаходяться в групі ризику, недостатньою кількістю якісно відібраних контрольних груп $[4,5,20,25]$, а також, найважливіше, рідкісністю даного захворювання [3]. Проблемою всіх європейських країн, у тому числі й України, є відсутність централізованих баз даних, що не дозволяє оцінити важливість цього питання та вчасно діагностувати злоякісні трофобластичні пухлини, ініційовані М3 [11].

Згідно із затвердженою у 2003 р. класифікацією МОЗ України [26], в поняття трофобластичної хвороби включаються наступні новоутворення:
- Хоріокарцинома;

- Трофобластична пухлина плацентарного майданчика;

- Епітеліоїдна трофобластична пухлина;

3 Міхурцева вагітність;

3 Повний M3;

- Частковий М3;

- Інвазивний M3;

- Метастатичний М3;

- Непухлинні трофобластичні ураження;

3 Вузлиібляшки плацентарного майданчика;

- Аномально збільшений плацентарний майданчик.

Виникнення даної патології залежить від багатьох факторів $[3,14,15]$, зокрема значне місце посідає генетична схильність. Ця патологія виникає в жінок дітородного віку, а її розвиток практично завжди асоційований з вагітністю, не залежачи від кількості попередніх пологів. В групу пухлин трофобласту включають різні форми міхурцевого занеску та хоріонкарциному [5, 9].

Вважається, що пухлинне перетворення трофобласту може відбутись під впливом інфекції на фоні недостатньої продукції естрогенів яєчниками, зумовленої генетичною патологією. Повний МЗ виникає при однобатьківській дисомії, коли з невідомих причин відбувається втрата материнських генів і дублювання батьківського гаплоїдного геному (зигота має каріотип 46XX) [1]. Інколи (у 5\% випадків) повний МЗ викликається заплідненням порожньої (без'ядерної) яйцеклітини двома сперматозоїдами, що призводить до утворення каріотипу 46XY або 46XX. Ембріон гине на ранніх термінах розвитку до встановлення плацентарного кровообігу [1, 2].

Частковий М3 викликаний триплоїдією в результаті запліднення яйцеклітини двома сперматозоїдами (диспермія) із затримкою гаплоїдного набору материнських хромосом. Клітини мають один гаплоїдний набір мате- 
ринських хромосом і диплоїдний набір батьківських хромосом (диандрогенетичний) - каріотип може бути 69XXY, 69XXX або 69XYY. В такому випадку ембріон найчастіше гине на 10-му тижні внутрішньоутробного розвитку $[1,7,19,24]$.

На даний момент доведено і зрозуміло, що повний і частковий МЗ - патогенетично абсолютно різні, хоча й споріднені захворювання. 3 описаного вище ясно, що повний М3 $є$ патогеномом повністю батьківського походження і зазвичай гомозиготний (XX); ядерна ДНК - батьківського походження, ДНК цитоплазми - материнського походження $[4,7,19,20]$, а в основі неповного М3 лежить відсутність материнського генетичного матеріалу (рис. 1).
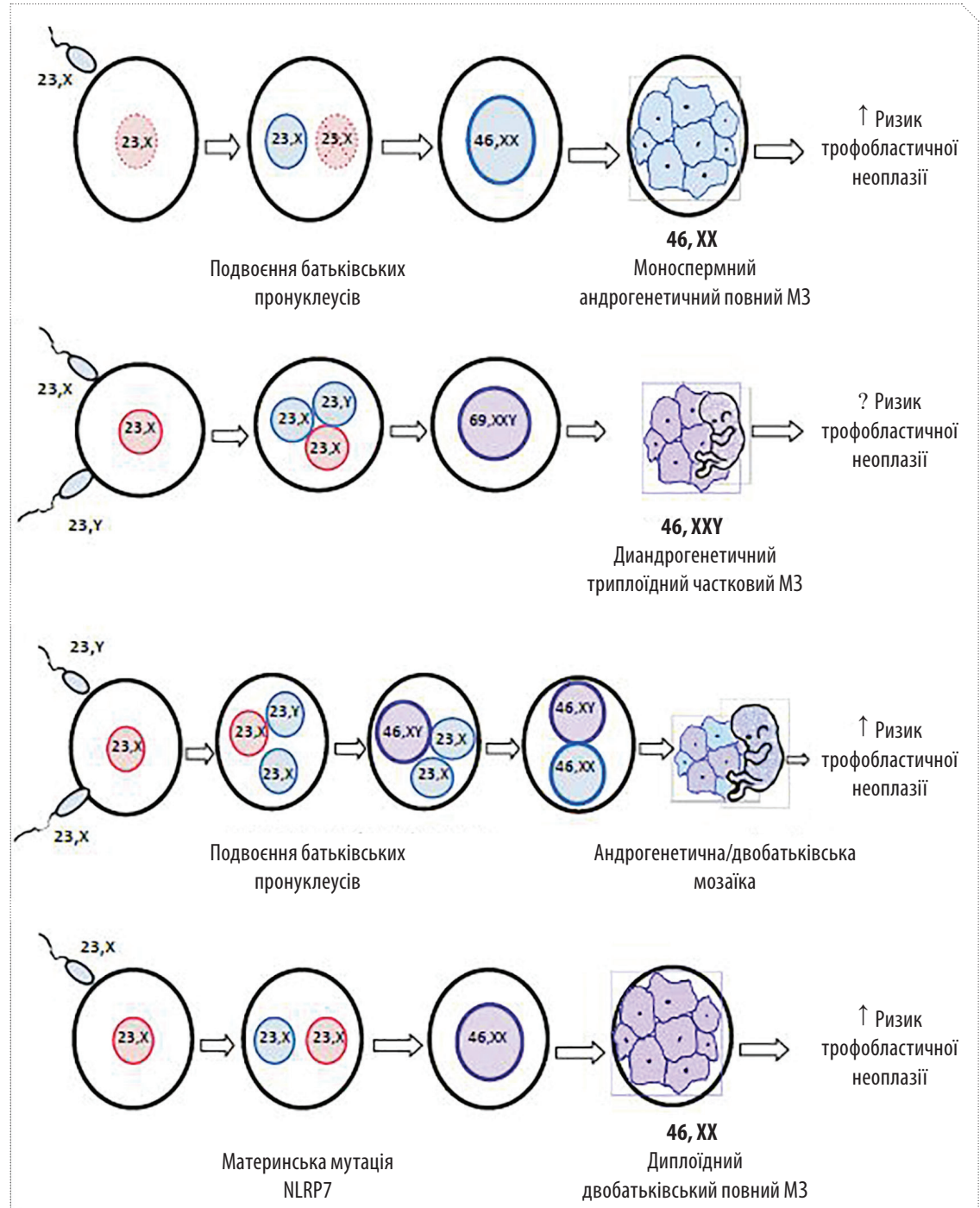

Рисунок 1. Патогенетичні механізми розвитку повного і часткового М3 (адаптовано 3 K.M. Steinberg et al., 2014 [28])

Серед різних варіантів трофобластичної хвороби в клінічній практиці найчастіше діагностують повний і частковий МЗ [27]. У сучасних класифікаціях ці патологічні процеси віднесені до доброякісних. Проте Європейська організація з лікування трофобластичної хвороби (European Organisation for Treatment of Trophoblastic Diseases, EOTTD) та Міжнародне товариство з вивчення трофобластичної хвороби (International Society for the Study of Trophoblastic Diseases, ISSTD) пропонують відносити повний та частковий М3 до передракових станів та реєструвати його як стадію 0 злоякісних трофобластичних пухлин $[4,7,20]$. На наш погляд, такий підхід має право на визнання, адже дозволяє привернути підвищену увагу клініцистів до своє- часної діагностики і особливо до профілактики розвитку ускладнень і малігнізації даної патології на ранніх етапах.

\section{Класифікація гестачійної} трофобластичної хвороби

На даний момент найбільш сучасною та поширеною у всьому світі $\epsilon$ класифікація FIGOWHO, 2002 (табл. 1).

Таблиця 1. Класифікація гестаційної трофобластичної Хвороби (FIGO-WHO, 2002)

\begin{tabular}{|c|c|}
\hline I стадія & Ураження, обмежене маткою \\
\hline II стадія & $\begin{array}{c}\text { Ураження, поширене за межі матки, але } \\
\text { обмежене статевими органами }\end{array}$ \\
\hline III стадія & Метастазування в легені \\
\hline IV стадія & Інші віддалені метастази з ураженням легень \\
або без нього
\end{tabular}

TNM-класифікація трофобластичних пухлин відсутня. Однак загальновідомо, що М3 відноситься до групи підвищеного ризику формування злоякісної пухлинної патології. Тому було розроблено критерії [1, 2, 6, 9, 14] ранньої діагностики онкологічної трансформації М3 після евакуації патологічного вмісту порожнини матки (табл. 2).

\section{Таблиця 2. Критерії діагностування злоякісних трофобластичних пухлин після евакуації М3 \\ Плато рівень ХГЛ за чотирикратного дослідження протягом 3-х тижнів (у 1, 7, 14 і 21 день) після евакуації М3 \\ Підвищення рівня ХГЛ на 10\% і більше за трикратного дослідження протягом 2-х тижнів (у 1,7 7 i 14 день) після евакуації М3 \\ Прояв ХГЛ через 6 місяців після евакуації МЗ \\ Гістологічно верифікована хоріонкарцинома, спровокована МЗ}

Поділ процесу на стадії у випадку постміхурцевої трофобластичної пухлини проводиться відповідно до анатомічної клінічної класифікації трофобластичної хвороби $[9,10,23]$.

\section{Морфологічна діагностика МЗ}

Гістологічна картина при гестаційній трофобластичній хворобі різноманітна. Вона може бути представлена як у вигляді зміненої строми з великими полігональними атиповими клітинами, так і у вигляді одношарового епітелію, яким вкрита стінка міхурця.

Патогістологічне дослідження плідного яйця при порушеній вагітності спрямовано в першу чергу на виключення діагнозу МЗ. Крім того, це дослідження надає важливу інформацію щодо персистенції гестаційної трофобластичної хвороби, а також впливає на планування подальшої тактики ведення пацієнтки. Так, при повному МЗ персистенція гестаційної трофобластичної хвороби спо- 
стерігається в 15-20\% випадків, серед яких 3-5\% становить хоріонкарцинома. При частковому М3 питома вага персистенції трофобластичної хвороби становить 1-4\%.

У зв'язку з цим при обох формах МЗ протокол спостереження за рівнем ХГЛ включає щотижневе тестування показників до отримання трьох послідовних нормальних рівнів гормону з наступним щомісячним визначенням ХГЛ протягом півроку. Також з огляду на необхідність профілактики персистенції трофобластичної хвороби рекомендується застосування ефективної контрацепції протягом усього періоду спостереження.

Якщо впродовж шести місяців зазначеного менеджменту персистенція МЗ виключається, паціентка знімається 3 диспансерного спостереження, що має особливе значення для жінок із активними репродуктивними планами.

Ще одним завданням патоморфолога $\epsilon$ не лише верифікація форми міхурцевого занеску, а й визначення патологічних процесів, які імітують молярну вагітність. До них відносяться особливості будови ворсин хоріона з вираженою проліферацією трофобласту на різних строках гестації, а також гідропічний аборт з характерними гідропічно зміненими ворсинами.

За умов трисомії, а також при андрогенетичному мозаїцизмі аномальна морфологія ворсин характеризується поліморфними формами з порушеними контурами.

Для типових випадків повного M3 характерні збільшені гідропічні ворсини з кавітацією та трофобластичними включеннями, виражена проліферація трофобласту в оточенні ворсин, що поєднується з цитологічною атипією. При цьому гестаційний міхур, амніон, пуповинний тяж та тканина ембріону відсутні. Типові випадки парціального міхурцевого занеску характеризуються двома типами ворсин: нормальної форми та гідропічно зміненими 3 мінімальною гіперплазією трофобласту, враховуючи синцитіотрофобласт, великими ворсинами 3 кавітацією та включеннями трофобласту. У цих ворсинах також можлива наявність не лише фетальної тканини, амніону та хоріонічного мішка, а й ядерних форм еритроцитів у стромальних судинах. Незважаючи на те, що морфологічні ознаки повного та парціального міхурцевого занесків відомі патоморфологам, будучи широко описані в доступних літературних джерелах, диференційна діагностика може викликати певні труднощі.

Для оптимізації діагностики та диференційної діагностики при повному М3, парціальному МЗ та немолярній вагітності використовують генетичні дослідження. Генетичні зміни у формі андрогенетичної диплоїдії при повному МЗ, диандрогенетична триплоїдія при парціальному МЗ та двобатьківська диплоїдія у більшості випадків немолярної вагітності дозволять з успіхом використовувати методи молекулярно-генетичного аналізу за допомогою проточної цитометрії, а також імуногістохімічний аналіз експресії маркерів р57 та Кі67.

Вперше генетичні маркери Кi67 і p57 для диференційної діагностики МЗ та гідропічних змін ворсин хоріона було використано D.P. Schammel та T. Bocklage у 1996 році. Зіставлення гістологічних ознак з даними проточної цитометрії відносно плоїдності ДНК дозволили встановити, що рівень експресії Кі67 допомагає відрізнити немолярну вагітність від МЗ. За умов парціального та повного МЗ експресія Кі67 спостерігалась у більше ніж 70\% клітин цитотрофобласту, тоді як рівень Кі67-позитивних клітин на тлі гідропічного аборту не перевищував 22\%. 3 огляду на те, що при повному та частковому М3 рівні експресії Кі67 в цитотрофобласті виявляються однаково високими, визначення даного маркера для диференціювання зазначених варіантів трофобластичної хвороби не застосовується. У 2001 році Castrillon та колеги виявили, що рівень експресії р57 може відрізнити диплоїдну форму повного М3 від диплоїдного аборту, а також від триплоїдного парціального МЗ. Так, за умов повного M3 імуногістохімічна реакція з р57 відсутня або виражена на дуже низькому рівні - до 10\% позитивних клітин. Таким чином, застосування комбінації двох імуногістохімічних маркерів Кі67 та p57 дозволяє диференційно діагностувати гідропічний аборт, а також парціальний та повний М3.

Мета дослідження: виявлення особливостей диференційної діагностики трофобластичної хвороби на ранніх термінах її розвитку.

\section{МАТЕРІАЛИ ТА МЕТОДИ ДОСЛІДЖЕННЯ.}

\section{КЛІНІЧНИЙ ВИПАДОК}

Дослідження проводилось на клінічній базі кафедри акушерства, гінекології та перинатології НМАПО ім. П.Л. Шупика за допомогою ультразвукового апарату Philips, ATL, HDI 1500 траснвагінальним трансд'юсером з частотою 7-9 мГц і в Центрі ультразвукової діагностики та інтервенційної сонографії клінічної лікарні «Феофанія» (м. Київ) на апараті General Electrics Logiq E9 Xdclear, а також у відділенні патоморфології Київського міського ендокринологічного центру та в лабораторії CSD Health Care (м. Київ).

Пацієнтка А. звернулась до фахівців кафедри акушерства, гінекології та перинатології клінічного відділення Українського державного інституту репродуктології НМАПО ім. П.Л. Шупика для підтвердження маткової вагітності в терміні 6-7 тижнів. Анамнестичні дані: вагітність перша, спадковий анамнез не обтяжений, хронічних захворювань не спостерігалось. На початку останнього менструального циклу пацієнтка перенесла лапаротомію, апендектомію з приводу гострого апендициту.

Під час проведення гінекологічного обстеження в дзеркалах виявлено: зовнішні статеві органи розвинуті звичайно, без особливостей. Слизова шийки матки не ерозована, звичайного кольору. Шийка матки не вкорочена та звичайної форми. При бімануальному дослідженні виявлено, що матка збільшена до 5-6 тижнів вагітності. Результати стандартних загальноклінічних обстежень (визначення групи крові та резус-фактора, загального клінічного аналізу крові та сечі, біохімічних показників, глюкози крові натще та бактеріоскопічного аналізу виділень) в межах норми.

Результати первинного УЗД в терміні 5-6 тижнів: вміст порожнини матки неоднорідний за рахунок двох округлих анехогенних утворень середніми розмірами 5,4х5,5 та 5,6×5,7 мм (рис. 2). В жодному з утворень не визначались жовточні мішки та ембріони. 3 метою підтвердження нормальної прогресуючої двоплідної вагітності пацієнтці було рекомендовано визначення сироваткового рівня $\beta$-субодиниці ХГЛ (рис. 8), а також повторне УЗД через 1 тиждень (рис. 3). 

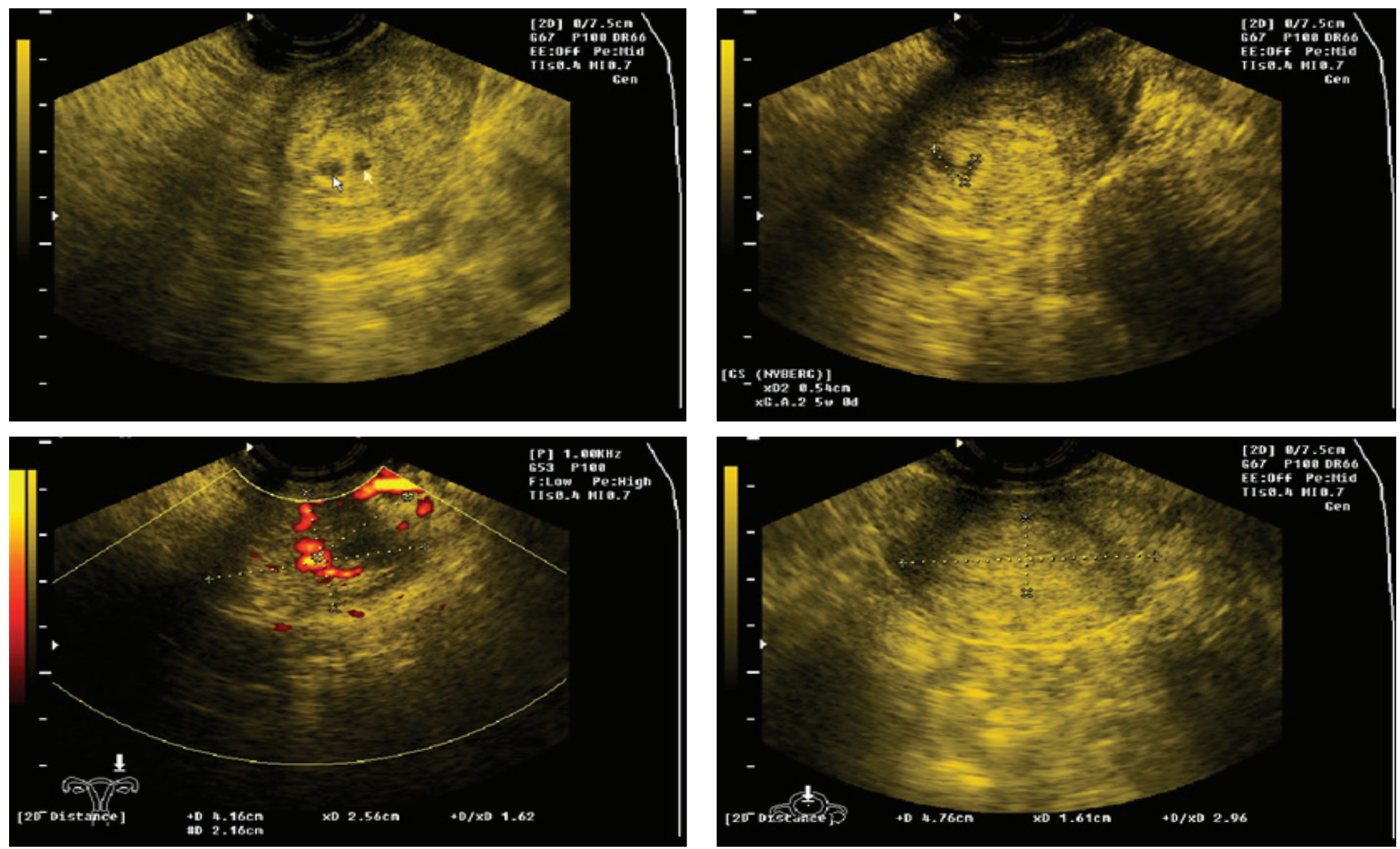

Рисунок 2. Результати УзД матки та яєчників пацієнтки А. (апарат Philips, ATL)

В порожнині матки візуалізуються два округлі анехогенні утворення без вмісту (двоплідна вагітність?). В лівому яєчнику - «жовте тіло вагітності».
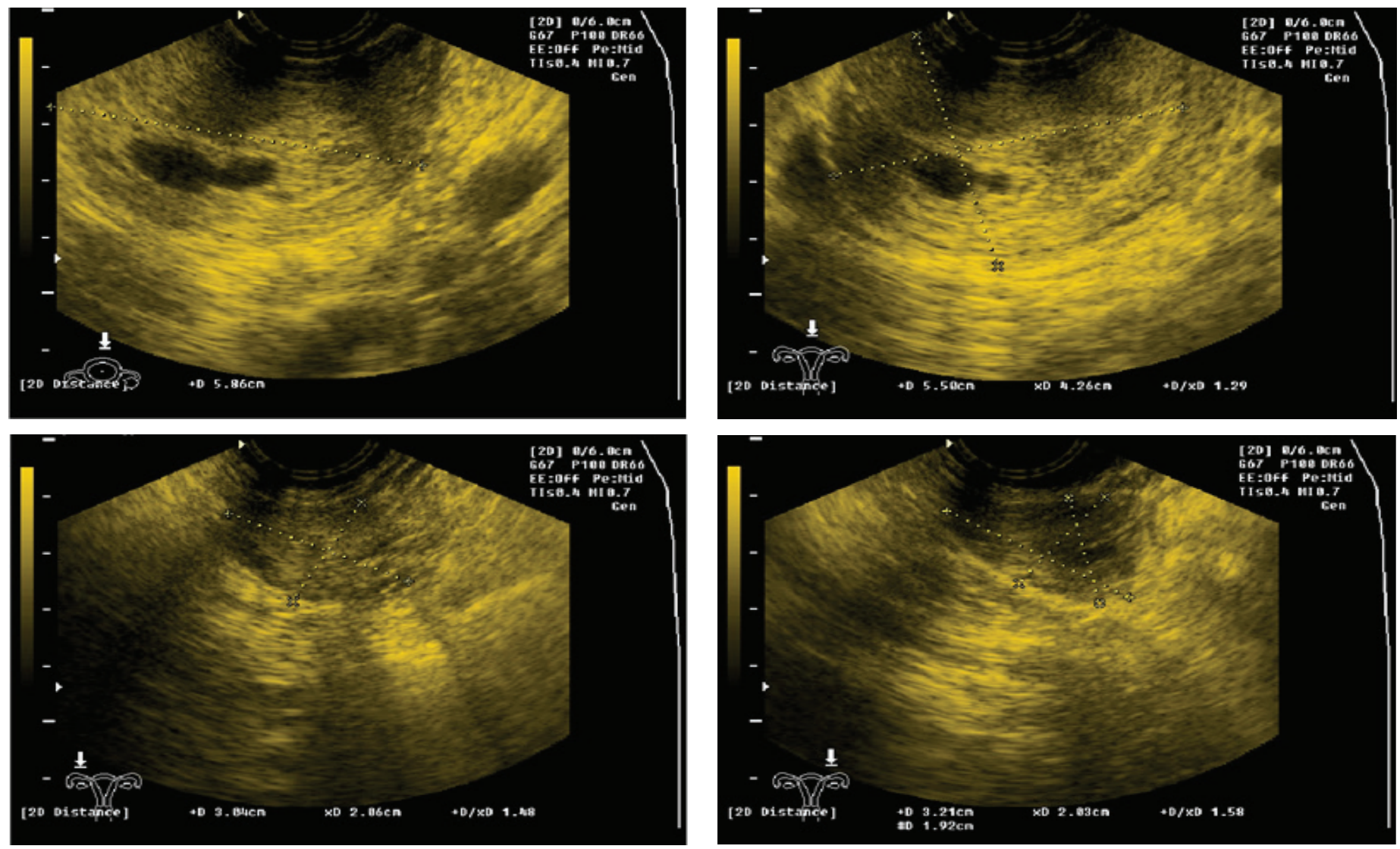

Рисунок 3. Результати УЗД матки та яєчників пацієнтки A. (апарат Philips, ATL)

В порожнині матки візуалізуються округлі анехогенні утворення без вмісту. Лівий яєчник містить «жовте тіло». Формування МЗ. 
Результатом вторинного ультразвукового сканування стала візуалізація вже трьох анехогенних міхурців діаметрами до 10 мм без будь-якого вмісту, що дозволило нам припустити формування М3 (рис. 3). Рівень $\beta$-субодиниці ХГЛ на момент повторного дослідження становив 23880 ОД/л (рис. 8).

Враховуючи сучасні принципи медичної етики та деонтології і з метою уточнення діагнозу (інший апарат, «інші очі» дослідника) пацієнтка була спрямована на додаткове УЗД до відділення ультразвукової діагностики та інтервенційної сонографії клінічної лікарні «Феофанія». В результаті цього дослідження також було діагностовано анембріонію, формування простого М3 (рис. 4).
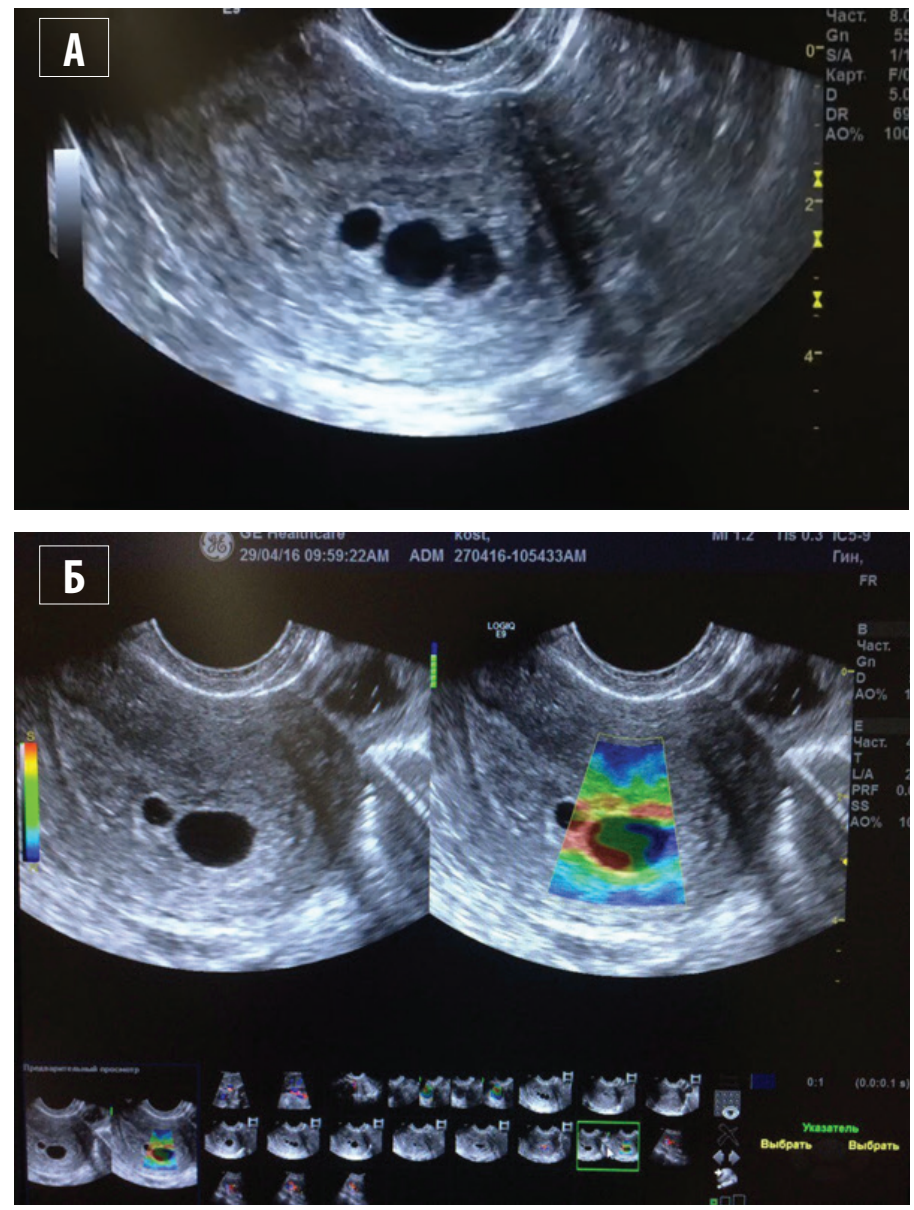

Рисунок 4. УЗД пацієнтки А. із застосуванням соноеластографії. Анембріонія. Формування M3 (апарат General Electrics, Logiq E9 Xdclear) A. На ехограмі три поряд розташовані анехогенні утворення різного діаметра (4 мм, 7 мм, 6 мм) з чіткими контурами, визначаються в центральних відділах порожнини матки.

Б. При використанні додатково до В-режиму методу компресійної еластографії в проекції хоріона визначаються ділянки значно підвищеної ехогенності (червоний колір) Незмінений хоріон при фізіологічній вагітності не містить таких щільних ділянок.

Враховуючи необхідність термінового завершення вагітності, пацієнтка А. була спрямована до гінекологічного стаціонару. Однак у гінекологічному відділенні було встановлено діагноз прогресуючої маткової вагітності, двійні, прийнято рішення щодо консервативного ведення хворої і призначено седативну зберігаючу терапію. Загальний стан жінки через різницю в діагнозах і, відповідно, подальші прогнози потребува в значної уваги, особливо стосовно психоемоційного стану.
В результаті консиліуму наступного дня було підтверджено діагноз анембріонія та прийнято рішення негайного виконання вакуум-екстракції вмісту порожнини матки 3 наступною патоморфологічною верифікацією діагнозу МЗ.

При первинному гістологічному дослідженні отриманих в результаті вакуум-аспірації мас було зроблено наступне патоморфологічне заключення: «гроноподобні розростання трофобласту, які складаються з міхурців різного розміру. Також спостерігається часткова дегенерація строми та гіпертрофія клітин синцитію і синцитіотрофобластичного шару». Тобто МЗ не було діагностовано.

Для уточнення гістологічного діагнозу скельця були направлені до патоморфологічного відділення Київського міського ендокринологічного центру, де діагноз часткового М3 в пацієнтки А. підтвердився. А саме: «Хоріон в препараті представлений декількома великими незрілими ворсинами з гідропічними змінами, нерівним порізаним контуром і одиничними інклюзіями трофобласту, але без явних ознак кавітації, а також численними ворсинами звичайного вигляду середніх і дрібних розмірів. Гіперплазія трофобласту помірна, виражена по периметру ворсин великих і середніх розмірів.

Стромальні судини в препараті запустілі, в децидуальній тканині ділянки атипових клітин імплантаційного трофобласту і вогнищеві некрози. Фрагменти стінки амніотичного мішка і фетальної тканини в зішкрібку відсутні» (рис. 5).

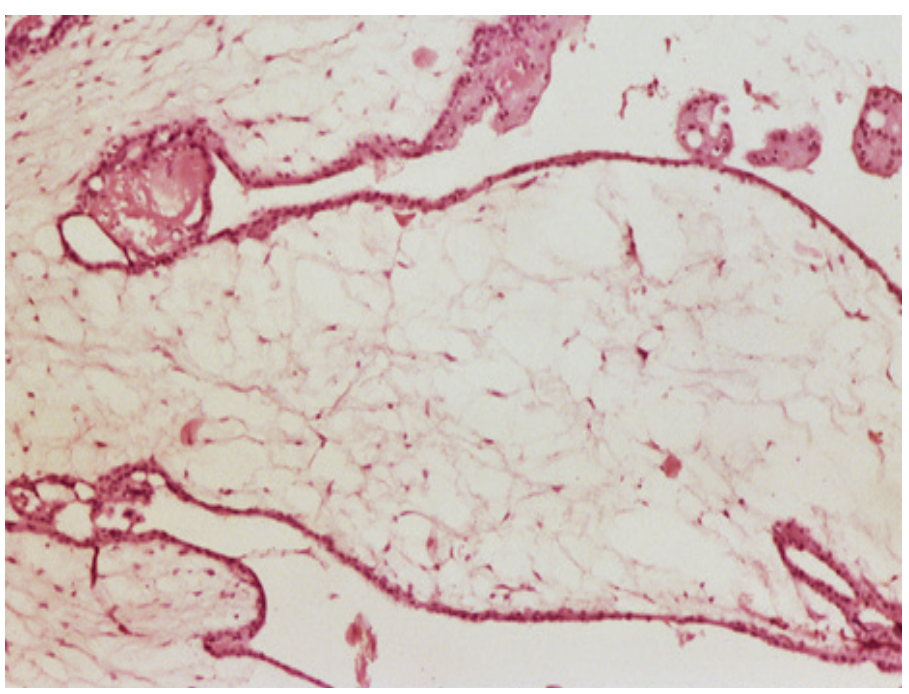

Рисунок 5. Парціальний М3 в терміні вагітності 5-6 тижнів

Незрілі гідропічні ворсини хоріона великих розмірів з нерівними контурами і осередковою помірною гіперплазією трофобласту по периметру ворсин. Характерні кістозні формації у ворсинах відсутні. Забарвлення гематоксилін-еозином, збільшення х 200.

Диференціальна діагностика була спрямована на виключення повного М3 і гідропічного аборту (подальший прогноз!), для чого виконані імуногістохімічні дослідження експресії p57 і Кі67. Експресія р57 була вираженою в ядрах клітин цитотрофобласту і клітинах строми ворсин, що характерно для диплоїдного спонтанного аборту і триплоїдного часткового М3 (рис. 1, 6). При повному М3 експресія цього маркера залишається низькою. Експресія Кі67 в ворсинах середніх розмірів також була високою (рис. 7).

Це $\epsilon$ відмінною рисою цитотрофобласту при обох типах молярної вагітності. При гідропічному аборті експресія Кі67 залишається слабкою (табл. 3). 


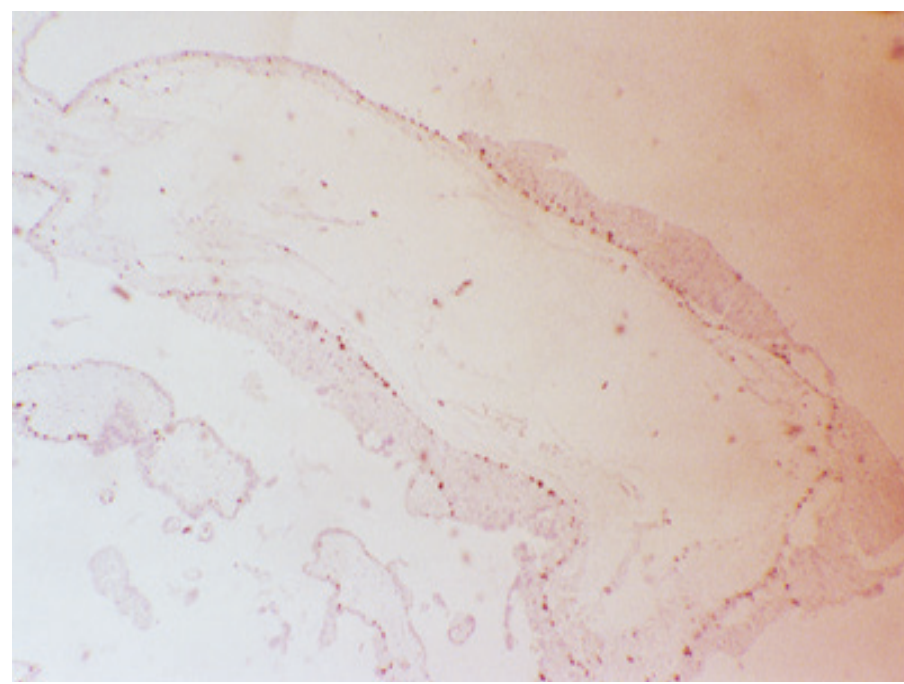

Рисунок 6. Парціальний М3 в терміні вагітності 5-6 тижнів

Експресія Кі67 по периметру ворсин в ядрах більшості клітин цитотрофобласту. Імуногістохімічна реакція з Кі67, збільшення х 100.

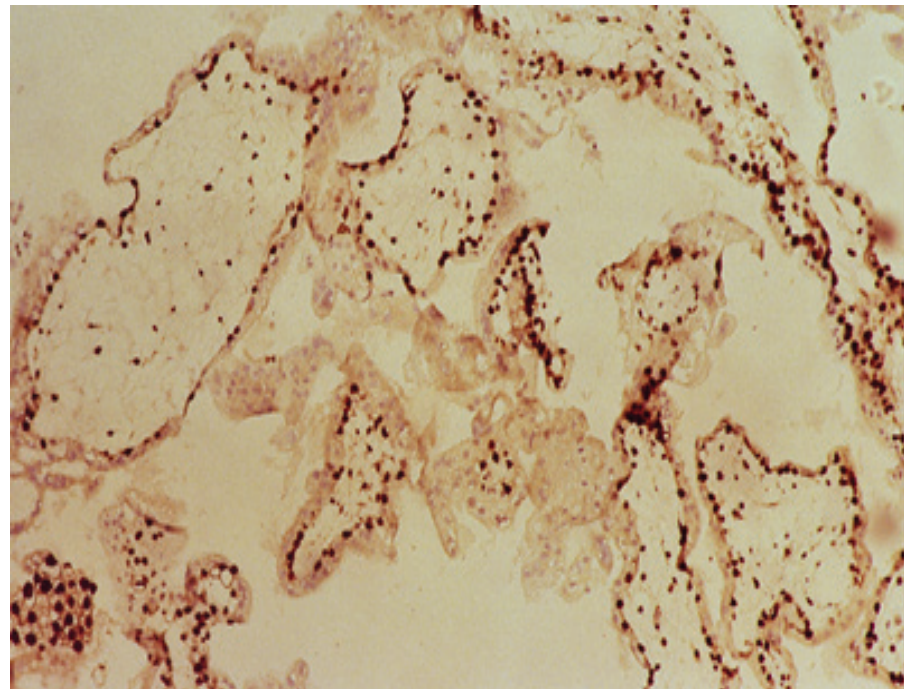

Рисунок 7. Парціальний МЗ в терміні вагітності 5-6 тижнів Експресія р57 виражена в ядрах клітин цитотрофобласту іпроміжного трофобласту, а також в стромальних клітинах ворсин хоріона середніх і дрібних розмірів, негативна реакція в клітинах синцитіотрофобласту. Імуногістохімічна реакція з р57, збільшення х 200.

Таблиця 3. Імуногістохімічні відмінності між гідропічним абортом, повним і частковим МЗ

\begin{tabular}{|c|c|c|}
\hline & $\begin{array}{c}\text { Експресія Кі67 в ядрах } \\
\text { цитотрофобласту по } \\
\text { периметру ворсин середніх } \\
\text { розмірів }\end{array}$ & $\begin{array}{c}\text { Експресія р57 в клітинах } \\
\text { цитотрофобласту i } \\
\text { стромальних клітинах } \\
\text { ворсин }\end{array}$ \\
\hline $\begin{array}{c}\text { Гідропічна } \\
\text { дегенерація }\end{array}$ & Низька (менш ніж 22\%) & Висока \\
\hline Частковий М3 & Висока (більш ніж 70\%) & Висока \\
\hline Повний М3 & Висока (більш ніж 70\%) & Низька \\
\hline
\end{tabular}

Після видалення міхурцевої маси із порожнини матки пацієнтка А. перебувала під постійним клінічним спостереженням. Надійним методом контролю за станом пацієнтки було як УЗД в динаміці, так і визначення рівня $\beta$-субодиниці ХГЛ як найбільш чутливого маркера наявності трофобластичних клітин в організмі (рис. 8). Дослідження проводи-

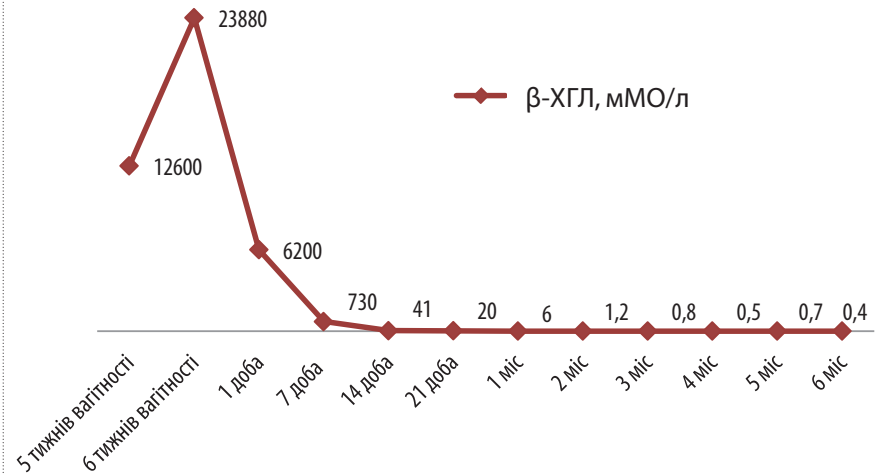

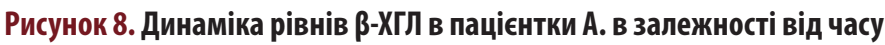

лось кожні 7 днів до виявлення негативного результату протягом шести місяців спостереження. Слід також зазначити, що пацієнтка А. отримувала комбінований оральний контрацептив (30 мкг етинілестрадіолу/2 мг дієногесту) 3 метою запобігання вагітності впродовж півроку після вакуум-евакуації міхурцевих мас. Слід ретроспективно зазначити, що одним із найбільш потребуючих уваги моментів менеджменту даного клінічного випадку став саме високий рівень тривоги та психоемоційного стресу жінки (вагітна чи невагітна?) під час відмінностей у постановці діагнозу i, як наслідок, різниці в рекомендаціях лікарів-гінекологів до прийняття рішення на консиліумі.

\section{ВИСНОВКИ}

1. Інтерпретацію випадків з патологією малих термінів вагітності повинні проводити лікарі-діагности спільно з лікарями-гінекологами, які мають достатній досвід та спеціальну підготовку з проблем трофобластичної хвороби.

2. Дані УЗД в динаміці та результати клініко-лабораторних досліджень повинні обов'язково враховуватись у комплексі.

3. Необхідно проводити додаткове навчання лікарів гінекологічних стаціонарів та жіночих консультацій з даної проблеми, оскільки вона залишається завжди актуальною 3 огляду на високий ризик перетворення фізіологічних станів вагітності на онкопатологію.

4. Радикальні рішення в таких випадках мають прийматися консиліумом лікарів.

5. Гістологічні дослідження мають проводити лікарі в спеціалізованих закладах (онкоцентри, наукові заклади 4-го рівня).

Зі збільшенням кількості вагітних жінок після лікування безпліддя, в тому числі методами допоміжної репродукції, схожі випадки з різних причин можуть траплятися частіше, тому лікарям, яким довірено спостерігати та лікувати таких пацієнток, слід завжди враховувати суттєві морально-психологічні та, можливо, додаткові юридичні аспекти, виникнення яких найчастіше можна передбачити і попередити. 
ПУХЛИНИ ТА ПЕРЕДПУХЛИННА ПАТОЛОГІЯ

\section{ЛITEPATУPA/REFERENCES}

1. Mangili, G., Lorusso, D., Brown, J., et al.

"Trophoblastic disease review for diagnosis and management: a joint report from the International Society for the Study of Trophoblastic Disease, European Organisation for the Treatment of Trophoblastic Disease, and the Gynecologic Cancer InterGroup." Int J Gynecol Cancer 24 (2014): 9-116.

2. Lurain, J.R.

"Gestational trophoblastic disease II: classification and management of gestational trophoblastic neoplasia." Am J Obstet Gynecol 204 (2011):11-8.

3. Ronnett, B.M., DeScipio, C., Murphy, K.M.

"Hydatidiform moles: ancillary techniques to refine diagnosis." Int J Gynecol Pathol 30 (2011): 101-16.

4. Ngan, H.Y., Bender, H., Benedet, J.L., et al.

"Gestational trophoblastic neoplasia, FIGO 2000

staging and classification." Int J Gynaecol Obstet 83 (2003): 175-7.

5. Barber, E.L., Schink, J.C., Lurain, J.R.

"Hepatic metastasis in gestational trophoblastic neoplasia: patient characteristics, prognostic factors, and outcomes."

J Reprod Med 59 (2014): 199-203.

6. Мещерякова, Л.А.

Трофобластические опухоли: возможности хирургического лечения / Л.А. Мещерякова,

В.П. Козаченко // Вестн. Рос. онкол. науч. Центра. - 2003. - №4. - С. 36-42.

Meshcheriakova, L.A., Kozachenko, V.P.

"Trophoblastic tumors: the possibilities of surgical treatment." Herald of Rus Oncol Scientific Center 4 (2003): 36-42.

7. Цип, Н.П.

Хирургический метод в лечении трофобластических опухолей / Н.П. Цип, Л.И. Воробьева //

Практ. Онкол. - 2008. - №3. - С. 179-185.

Tsyp, N.P., Vorobyeva, L.I.

"Surgical method in the treatment of trophoblastic tumors." Pract Oncol 3 (2008): 179-85.

8. Matsui, H., Suzuka, K., Yamazawa, K., et al.

"Relapse rate of patients with low-risk gestational trophoblastic tumor initially treated with single-agent chemotherapy." Gynecol Oncol 96.3 (2005): 616-20.

9. Behtash, N., Ansari, S., Sarvi, F.

"Successful pregnancy after localized resection of perforated uterus in choriocarcinoma and a

literature review." Int J Gynecol Cancer 16 Suppl 1 (2006): 445-8.

10. Hoekstra, A.V., Keh, P., Lurain, J.R.

"Placental site trophoblastic tumor: a review of 7 cases and their implications for prognosis and treatment." J Reprod Med 49.6 (2004): 447-52.

11. Papadopoulos, A.J., Foskett, M., Seckl, M.J., et al.

"Twenty-five years' clinical experience with placental site trophoblastic tumors." J Reprod Med

47.6 (2002): 460-4.

12. Kohorn, E.

"The draft of EOTTD protocol for diagnosis and treatment of trophoblastic disease of pregnancy."

(2012).

13. Berkowitz, R.S., Goldstein, D.P., Seckl, M.J., et al.

"Placental site trophoblastic tumour: clinical features and management." Clin Obstet Gynecol 50 (2007): 112-22.

14. Hui, P., Maesta, I., et al.

"Placental site trophoblastic tumour: clinical features and management." Gynecol Oncol 99.3

(2005): 603-7.

15. Zeng, X., Liu, X., Tian, Q., et al.

"Placental site trophoblastic tumor: A case report and literature review." Intractable Rare Dis Res

4.3 (2015): 147-51.

16. Janni, W., Hantschmann, P., Rehbock, J., et al.

"Successful treatment of malignant placental site trophoblastic tumor with combined cytostaticsurgical approach: case report and review of literature." Gynecol Oncol 75.1 (1999): 164-9.

17. Metindir, J., Pak, I., Ozdilekcan, C., Eren, E.

"Chemoresistant placental site trophoblastic tumor with hilar lymph node metastasis: an unusual site of involvement." Gynecol Oncol 96.2 (2005): 552-5.

18. Eysbouts, Y.K., Massuger, L., Thomas, C., et al.

"Dutch Risk Classification and FIGO 2000 for Gestational Trophoblastic Neoplasia Compared." Int J Gynecol Cancer 26.9 (2016): 1712-16.

19. Brown, J., Naumann, R.W., Seckl, M.J., Schink, J.

"15 years of progress in gestational trophoblastic disease: Scoring, standardization, and salvage." Gynecol Oncol 144.1 (2017): 200-7.

20. Yamada, Y., Ohira, S., Yamazaki, T., Shiozawa, T.

"Ectopic Molar Pregnancy: Diagnostic Efficacy of Magnetic Resonance Imaging and Review of the Literature." Case Rep Obstet Gynecol (2016): 7618631.
21. Niknejadi, M., Ahmadi, F., Akhbari, F.

"Imaging and Clinical Data of Placental Site Trophoblastic Tumor: A Case Report." Iran J Radiol 13.2 (2016): e18480.

22. Manthati, S., Pratumvinit, B., Hanyongyuth, R., et al.

"Circulating free soluble fms-like tyrosine kinase-1 during late first trimester in relation with placental volume as a surrogate for trophoblastic production: A physiology study in low-risk cohort." J Matern Fetal Neonatal Med Online Feb 5 (2017): 1-8, D0I: 10.1080/14767058.2016.1235697.

24. Begum, J., Palai, P., Ghose, S.

"Complete molar pregnancy in postmenopausal women." J Midlife Health 7.2 (2016): 91-3.

25. Mohamed, S.A., Al-Hendy, A., Ghamande, S., et al.

"Atypical Presentations of Molar Pregnancy: Diagnostic Roles of Imaging, $\beta$-Human Chorionic Gonadotropin Measurement, and p57 Immunostaining." J Ultrasound Med 35.3 (2016): 643-9.

26. Наказ М03 України № 641/84 від 31.12.2003.

«Про вдосконалення медико-генетичної допомоги в Україні».

Order of the MOH of Ukraine № 641/84 from 31.12.2003.

"On the improvement of medical-genetics care in Ukraine."

27. Site of Dr. Urvashi Surti, Department of Pathology of University of Pittsburgh, USA. Available from: [http://path.upmc.edu/personnel/faculty/Surti.htm], last accessed Apr 1, 2017.

28. Steinberg, K.M., Schneider, V.A., Graves-Lindsay, T., et al.

"Single Haplotype Assembly of the Human Genome From a Hydatidiform Mole." Genome

Research 12.24 (2014): 2066-76. 


\section{Fertilovit ${ }^{\circledR}$}

\section{for a new life}

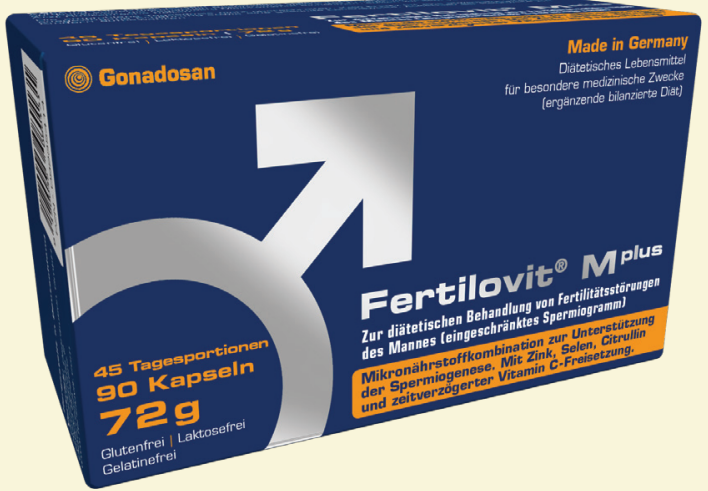

\section{Fertilovit ${ }^{\circledR}$ M $^{\text {plus }}$}

о7 Підготовка сперматозоїдів до запліднення в тому числі ДРТ;

ơ При екскреторно-токсичному безплідді;

о7 При ідіопатичному безплідді;

о’ При фрагментації ДНК сперматозоїдів;

ơ Сприяє активному захисту сперматозоїдів від оксидативного стресу

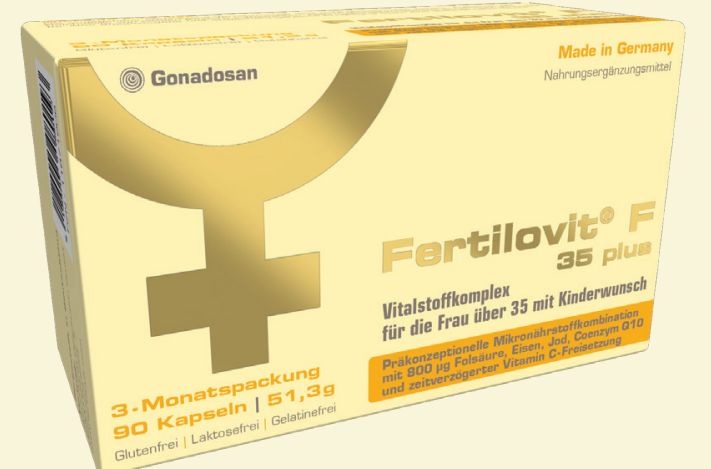

Fertilovit ${ }^{\circledR}$ F35plus

† Прегравідарна підготовка до вагітності в тому числі ДРТ;

ㅇ Покращує якість і кількість ооцитів;

† Покращує період передзародкового розвитку;

ㅇ Сприяє нормальному перебігу вагітності;

† Запобігає формуванню вад розвитку плода

\section{АНТИОКСИДАНТНИЙ ПОЛІВІТАМІННИЙ КОМПЛЕКС ФЕРТІЛОВІТ РЕЗУЛЬТАТИВНЕ РІШЕННЯ ДЛЯ ПОДРУЖНІХ ПАР!}

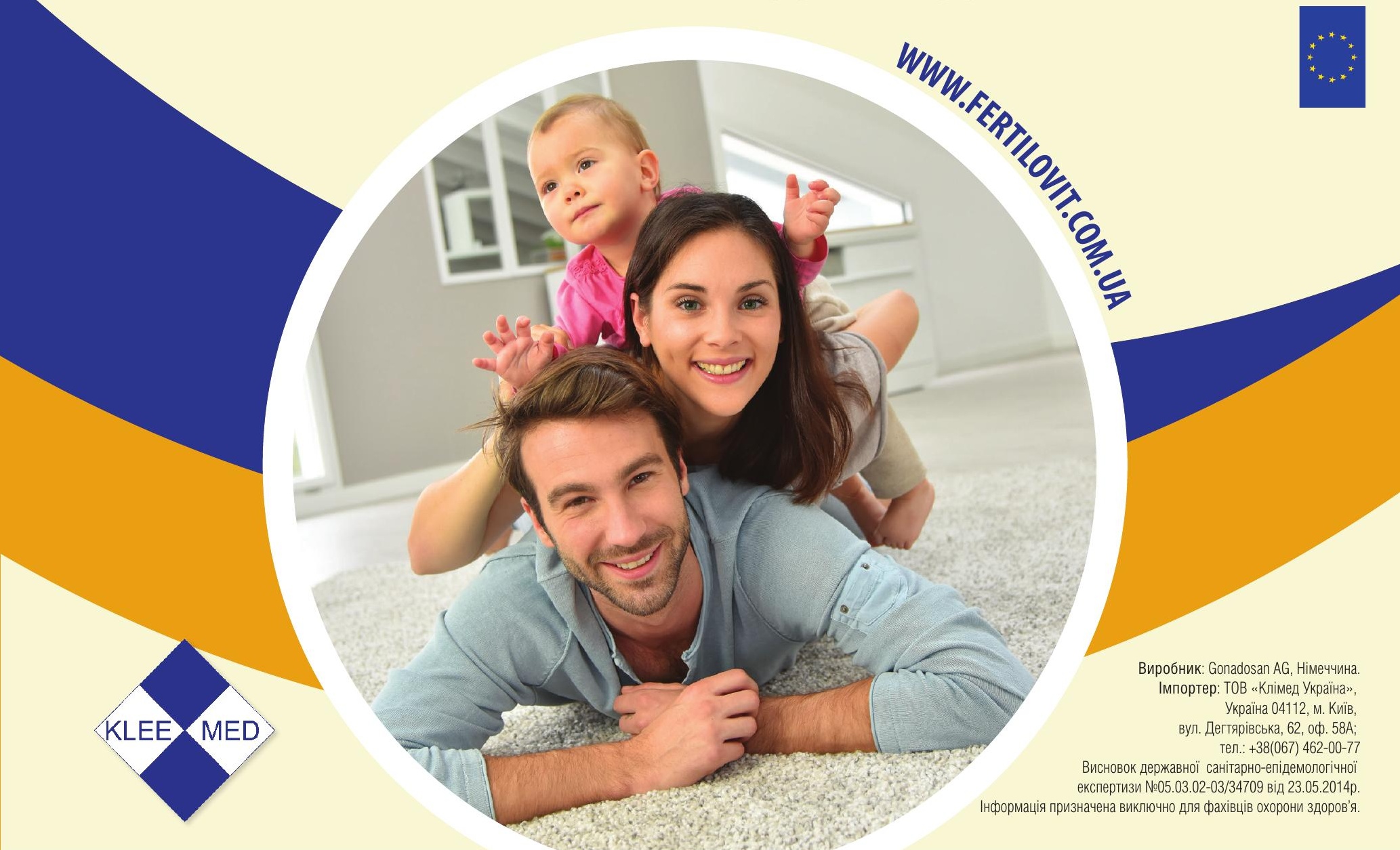




\section{ПРОБЛЕМНІ ПИТАННЯ ДІАГНОСТИКИ ТРОФОБЛАСТИЧНОӦ ХВОРОБИ}

Н.Ю. Педаченко, д. мед. н., доцент, професор кафедри акушерства, гінекології та перинатології НМАПО ім. П.Л. Шупика

0.І. Мухомор, к. мед. н., керівник Центру ультразвукової діагностики та інтервенційної сонографії клінічної лікарні «Феофанія», м. Київ

К.Л. Аветисьян, к. мед. н., зав. відділенням патоморфології Київського міського клінічного ендокринологічного центру

Ю.С. Денисенко, лікар акушер-гінеколог, інтерн кафедри акушерства, гінекології та перинатології НМАПО ім. П.Л. Шупика

Стаття присвячена дослідженню проблем діагностики трофобластичної хвороби в практичній діяльності лікаря акушера-гінеколога. Наразі немає єдиної стратегї̈ у виявленні та лікуванні гестаційної трофобластичної хвороби, оскільки відсутня чітка діагностика цього стану. Патологія має мультифакторний характер, що також пов'язано $з$ деякими труднощами у своєчасному виявленні гестаційної трофобластичної хвороби. На даний момент доведено, що виникнення цієї патології залежить від багатьох факторів, зокрема важливу роль відіграє патогенетична схильність.

В представленому дослідженні вивчалися особливості диференційної діагностики трофобластичної хвороби на ранніх етапах розвитку за допомогою ультразвукового та патогістохімічного досліджень. Було доведено, що ці дослідження відіграють важливу роль в розрізненні молярної та маткової вагітностей. Наведено клінічний випадок, в якому відзначено розбіжності в діагнозах вагітної пацієнтки. Також відзначено необхідність дотримання сучасних принципів медичної етики та деонтології (інший апарат, «інші очі» дослідника).

Як відзначають автори статті, інтерпретацію випадків з патологією малих термінів вагітності повинні здійснювати лікарі-діагности спільно $з$ лікарями-гінекологами, які мають достатній досвід та спеціальну підготовку з проблем трофобластичної хвороби. При цьому дані ультразвукового дослідження в динаміці та результати клініколабораторних досліджень повинні обов'язково враховуватись у комплексі. Гістологічні дослідження мають проводити лікарі в спеціалізованих закладах (онкоцентри, наукові заклади 4-го рівня). Дана проблема продовжує залишатись актуальною з огляду на високий ризик перетворення фізіологічних станів вагітності на онкопатологію, і радикальні рішення в таких випадках мають прийматися консиліумом.

Зі збільшенням кількості вагітних жінок після лікування безпліддя, в тому числі методами допоміжної репродукції, схожі випадки з різних причин можуть траплятися частіше. Тому лікарям, яким довірено спостерігати та лікувати таких пацієнток, слід завжди враховувати суттєві морально-психологічні та, можливо, додаткові юридичні аспекти, виникнення яких найчастіше можна передбачити і попередити.

Ключові слова: трофобластична хвороба, повний міхурцевий занесок, частковий міхурцевий занесок, хоріонічний гонадотропін, онкологічна трансформація.

\section{ПРОБЛЕМНЫЕ ВОПРОСЫ ДИАГНОСТИКИ ТРОФОБЛАСТИЧЕСКОЙ БОЛЕЗНИ}

Н.Ю. Педаченко, д. мед. н., доцент, профессор кафедры акушерства, гинекологии и перинатологии НМАПО им. П.Л. Шупика

А.И. Мухомор, к. мед. н., руководитель Центра ультразвуковой диагностики и интервенционной сонографии клинической больницы «Феофания», г. Киев

К.Л. Аветисьян, К. мед. н., зав. отделением патоморфологии Киевского городского клинического эндокринологического центра

Ю.С. Денисенко, врач акушер-гинеколог, интерн кафедры акушерства, гинекологии и перинатологии НМАПО им. П.Л. Шупика

Статья посвящена исследованию проблем диагностики трофобластической болезни в практической деятельности врача акушера-гинеколога. На сегодня нет единой стратегии в выявлении и лечении гестационной трофобластической болезни, поскольку отсутствует четкая диагностика этого состояния. Патология имеет мультифакторный характер, что также связано с некоторыми трудностями в своевременном выявлении гестационной трофобластической болезни. На данный момент доказано, что возникновение этой патологии зависит от многих факторов, в частности важную роль играет патогенетическая предрасположенность.

В представленном исследовании изучались особенности дифференциальной диагностики трофобластической болезни на ранних этапах развития с помощью ультразвукового и патогистохимического исследований. Было доказано, что эти исследования играют важную роль в различении молярной и маточной беременностей. Приведен клинический случай, в котором отмечены расхождения в диагнозах беременной пациентки. Также отмечена необходимость соблюдения современных принципов медицинской этики и деонтологии (другой аппарат, «другие глаза» исследователя).

Как отмечают авторы статьи, интерпретацию случаев с патологией малых сроков беременности должны осуществлять врачи-диагносты совместно с врачамигинекологами, которые имеют достаточный опыт и специальную подготовку по проблемам трофобластической болезни. При этом данные ультразвукового исследования в динамике и результаты клинико-лабораторных исследований должны обязательно учитываться в комплексе. Гистологические исследования должны проводить врачи в специализированных учреждениях (онкоцентры, научные учреждения 4-го уровня). Данная проблема продолжает оставаться актуальной, учитывая высокий риск трансформации физиологических состояний беременности в онкопатологию, и радикальные решения в таких случаях должны приниматься консилиумом.

С увеличением количества беременных женщин после лечения бесплодия, В том числе методами вспомогательной репродукции, подобные случаи по разным причинам могут случаться чаще. Поэтому врачам, которым доверено наблюдать и лечить таких пациенток, следует всегда учитывать существенные морально-психологические и, возможно, дополнительные юридические аспекты, возникновение которых чаще всего можно предусмотреть и предупредить.

Ключевые слова: трофобластическая болезнь, полный пузырный занос, частичный пузырный занос, хорионический гонадотропин, онкологическая трансформация.

\section{PROBLEMATIC ISSUES OF DIAGNOSIS OF TROPHOBLASTIC DISEASE}

N.Y. Pedachenko, MD, professor, associate professor at the Department of Obstetrics, Gynecology and Perinatology of the NMAPE named after P.L. Shupyk

0.I. Mukhomor, PhD, head of the Center for Ultrasound Diagnostics and Interventional Sonography of the Clinical Hospital "Feofania", Kyiv

K.L. Avetisyan, PhD, head of the Department of Pathomorphology of Kyiv City Clinical Endocrinology Center

Y.S. Denysenko, obstetrician gynecologist, intern at the Department of Obstetrics, Gynecology and Perinatology of the NMAPE named after P.L. Shupyk

The article investigates the difficulties of diagnosis of trophoblastic disease in practice. Till nowadays there is no general strategy in the detection and treatment of gestational trophoblastic disease, as there is no clear status. The diagnosis of this pathology is multifactorial in nature, which also presents some difficulties in the timely detection of gestational trophoblastic disease. This shown that the occurrence of this disease depends on many factors, including the important role of pathogenetic predisposition.

In the current study the features of diferrential diagnosis of trophoblastic disease in the early stages of development by ultrasonography and hystologycal analysis were investigated. It was proved that these studies play an important role in the differentiation of uterine molar pregnancy. A clinical case is presented, in which disagreements in diagnoses of a pregnant patient are noted. Also there is a need to respect modern principles of medical ethics and deontology (another device, "other eye" of researcher).

As the authors of the article notes, the interpretation of cases with pathology of small pregnancy terms should implemented by doctors of diagnosts together with gynecologists, who have sufficient experience and special training on the problems of trophoblastic disease. In this case, the ultrasound data in the dynamics and the results of clinical and laboratory studies should be taken into account in the complex. Histological studies should be carried out by doctors in specialized institutions (oncological centers, scientific institutions of the 4th level). This problem continues to be relevant, given the high risk of transformation of the physiological conditions of pregnancy into oncopathology, and radical decisions in such cases should be taken by the consilium.

With the increase in the number of pregnant women after infertility treatment, including methods of assisted reproduction, such cases can happen more often for different reasons. Therefore doctors who are entrusted to watch and treat such patients should always take into account the significant moral, psychological and possibly additional legal aspects, the occurrence of which can often be foreseen and prevented.

Keywords: trophoblastic disease, mollar pregnancy, malignant tumor pathology, human chorionic gonadotropin, cancer transformation. 